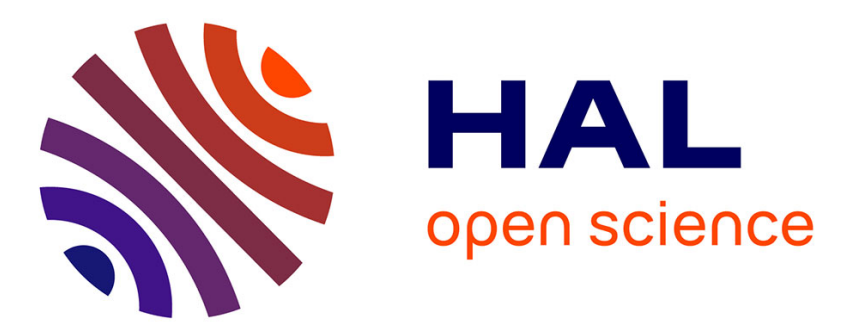

\title{
Experimental Study on Induction Heating Equipment Applied in Wireless Energy Transfer for Smart Grids
}

Rui Neves-Medeiros, Anastassia Krusteva, Stanimir Valtchev, George Gigov, Plamen Avramov

\section{To cite this version:}

Rui Neves-Medeiros, Anastassia Krusteva, Stanimir Valtchev, George Gigov, Plamen Avramov. Experimental Study on Induction Heating Equipment Applied in Wireless Energy Transfer for Smart Grids. 5th Doctoral Conference on Computing, Electrical and Industrial Systems (DoCEIS), Apr 2014, Costa de Caparica, Portugal. pp.486-493, 10.1007/978-3-642-54734-8_54 . hal-01274815

\section{HAL Id: hal-01274815 \\ https://hal.inria.fr/hal-01274815}

Submitted on 16 Feb 2016

HAL is a multi-disciplinary open access archive for the deposit and dissemination of scientific research documents, whether they are published or not. The documents may come from teaching and research institutions in France or abroad, or from public or private research centers.
L'archive ouverte pluridisciplinaire HAL, est destinée au dépôt et à la diffusion de documents scientifiques de niveau recherche, publiés ou non, émanant des établissements d'enseignement et de recherche français ou étrangers, des laboratoires publics ou privés. 


\title{
Experimental Study on Induction Heating Equipment Applied in Wireless Energy Transfer for Smart Grids
}

\author{
Rui Neves-Medeiros ${ }^{1}$, Anastassia Krusteva ${ }^{2}$, \\ Stanimir Valtchev ${ }^{1}$, George Gigov ${ }^{2}$ and Plamen Avramov ${ }^{2}$, \\ ${ }^{1}$ UNINOVA-CTS and ${ }^{2}$ Dept. of Electrical Engineering, FCT/UNL, Portugal \\ ${ }^{3}$ Research and Development Sector, TUS, Bulgaria
}

\begin{abstract}
This work is focused on the design of the contactless energy transmitters and testing of their electrical parameters, varying the working frequency in the $\mathrm{kHz}$ range. The intended application is related to the possibility to make most efficient wireless charging of different batteries from the grid, guaranteeing more acceptable use of the electric vehicles.
\end{abstract}

Keywords: transmitter; contactless; wireless; energy; power; converter; grid; battery; electric vehicles

\section{Introduction}

Wireless On-Line Electric Vehicle Energy Transfer (WOLEVET) is a user-project within the Seventh Framework Programme (FP7) project Distributed Energy Resources Research Infrastructures (DERri) focused on battery charging when Wireless Energy Transfer (WET) is included. An exchange of energy is planned between the AC grid, the battery and the contactless energy converter. The wireless energy transfer is defined as "On-line" because of the varying position of the energy receiver in relation to the energy transmitter. To experiment this movement the energy receiver was displaced at different distance to the fixed charging station. The described experiments were aimed to prove the most efficient energy transfer conditions that will facilitate the integration of electric vehicles (EV) in micro-grids, adding storage capacity (EV batteries) to the grid. This integration will reduce the battery size as the necessary energy will be directly available from the nearby source of the grid. This is very important as the price of a propulsion battery is now roughly $80 \%$ of the EV price. Smaller batteries mean fewer cells and lower pollution.

The reported work is dedicated to the design and experimentation of a contactless energy transmitter/receiver set involving some available high frequency (HF) generators, most of them originally dedicated to induction and dielectric heating. The shape and construction of the inductors that guarantee a good magnetic coupling and best efficiency is presented. The magnetic coupling is tested at real power of one or more $\mathrm{kW}$. The important choice of the power inverter parameters is limited to the type of resonance and the switching frequencies of the inverter. 
After the introduction, the Chapter 2 establishes a relation between this work and the scope of the conference. Chapter 3 explains the problem to be solved referencing previous works. Experimental achievements are revealed in Chapter 4 and followed by some conclusions in Chapter 5 .

\section{Relationship to Collective Awareness Systems}

The recently adopted concept of Smart Grids is preparing our society to consider the inclusion of individual lower power generators into the energy system. Those individual generators will need a more complex control than the traditional grids, but some benefits will arise, e.g. better efficiency, more safety, more reliability and more power delivered to the system.

Wireless charging of batteries can be used to easily associate EV with the smart grid. In fact, if the bi-directional flux of energy will be made possible than every vehicle can be seen as a collective energy reserve and the grid will be able to manage all the energy portions resulting in peak shaving or longer time storage.

From the private users' point of view, the cars and other devices with significant amount of stored energy would need to be available to a more complex but profitable control system that will meet the social goals of reducing the price and ecological footprint and increasing the safety associated with the batteries maintenance.

Certainly this contribution of the EV in re-utilizing the distributed energy would not be enough to substitute a conventional power plant, but it would help tracing load profiles for the major cities helping to better plan the operation of the regional dam or coal power plant reducing their costs. For all these reasons, the EV charged wirelessly is seen as a Collective Awareness System.

\section{State-of-the-Art}

The EV is becoming a necessity due to environmental problems and growing prices of classical energy production. The batteries of the new vehicles will require a large number of charging in different places and moments. The knowledge about the resonant WET became very important. The study of the Series Loaded Series Resonant (SLSR) converter places it as suitable for the WET [1]. There are other possible resonant configurations too [2].

The operation of SLSR converter is analyzed in many articles, e.g. in [1] but to obtain a rapid and accurate reaction of this circuit remains a problem. The existence of stored energy in the resonant reactance elements (inductance and capacitance) makes the direct control of the power switches quite difficult, especially when the circuit elements are not ideal (WET). Many articles are published, aimed at resonant converters control, usually including calculation of normalized phase-plane trajectory as in [3]. A more complex calculation block (implemented as FPGA) is shown in [4].

All the known methods are not reacting immediately to the demand of the resonant tank as they measure and control the resonant current. The future Instant Energy Control (IEC) circuits that respond not only to the resonant current but more to the 
resonant capacitor voltage are presented in [1] and [5]. The IEC allows safer operation of the transmitter, but there is a lot to do for the bi-directional energy transfer. The charged vehicle is supposed to give back energy to the common grid.

The control of the bi-directional energy exchange is expected to be similar to the already known solutions but will be necessary to involve a new information grid, comparable to the mobile network although much faster. One of the main new functions will be to recognize and authorize the car (Fig.1), efficiently enough, to receive or to deliver energy passing near the transmitter cells and to continue this interchange with the next cell. This problem is similar to the requirements that other smart grid versions will ask from the information technology.

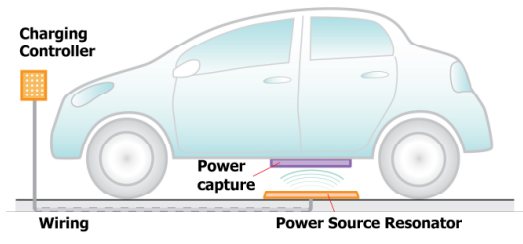

Fig. 1. Delphi Automotive's wireless electric-vehicle [6].

As referred in [6], the unit sales of wireless EV chargers in North America is expected to reach about 10,000 in 2014 and increase to more than 132,000 units by the end of the decade.



Fig. 2. The main blocks of the inductive charger [7].

Fig.2 illustrates the AC power (Power Supply) being supplied to the EV (Load) which concept is also reported in [8] and [9]. The circuit operates as following: the AC supply voltage is rectified and converted to a high frequency AC (tens or hundreds of $\mathrm{kHz}$ ) within the charger station. Based on the resonant processes this high frequency power is transferred to the EV side by induction. Finally the receiver converts the high frequency AC power into a DC power for the battery charging. 


\section{Experimental Results}

The main performed tasks were aimed to verify the efficient operation of the inductively coupled set of transmitter/receiver. This included the design of the transmitter, the proper choice of the resonant capacitor, the definition of the power for the experiments, the reconfiguration of the existing (from induction heating) system of coupling, the necessary measurements and analyses of the obtained parameters.

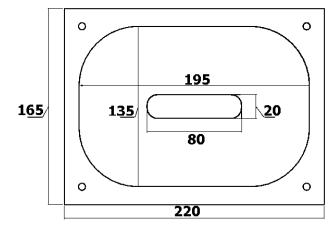

Fig. 3. Transmitter magnetic core design with dimensions in $\mathrm{mm}$.

The designed transceiver (transmitter/receiver), illustrated in Fig.3 consists in ferrite core (FLUXTROL 50) and coils of copper tube with $\mathrm{d}=6 \mathrm{~mm}, \mathrm{~N}=5$ and water cooling. The thickness of the plate is $15 \mathrm{~mm}$ and the internal column is $9 \mathrm{~mm}$ thick. The parameters of the coil are: $\mathrm{L}=40.6 \mu \mathrm{H}$ and $\mathrm{R}=82.0 \mathrm{~m} \Omega$.

Four different experiments were attempted with four different power sources.

In this text the, indexes "1" and "2" correspond respectively to the primary and the secondary sides of the transformer (magnetic link). The primary side of the transformer will be also referred as "the sender" or "the first coil" and the secondary side as "the receiver" or "the second coil". The index " case "R" and "D" correspond to electrical Resistance and Distance respectively. Lower case "r" and "d" correspond to radius and diameter.

\subsection{First Experiment - HF Signal Generator}

This experiment was aimed to determine the resonant frequency of the transceiver at low power.

Table 1. Circuit parameters for $\mathrm{f}_{\mathrm{r}}=145-175 \mathrm{kHz}$.

\begin{tabular}{|c|c|c|c|c|c|c|c|}
\hline $\begin{array}{c}\mathbf{D} \\
{[\mathbf{c m}]}\end{array}$ & $\begin{array}{c}\mathbf{f}_{1 \mathbf{r}} \\
{[\mathbf{k H z}]}\end{array}$ & $\begin{array}{c}\mathbf{U}_{1 \max } \\
{[\mathbf{V}]}\end{array}$ & $\mathbf{I}_{\mathbf{1} \max }[\mathbf{A}]$ & $\begin{array}{c}\mathbf{f}_{2 \mathbf{r}} \\
{[\mathbf{k H z}]}\end{array}$ & $\mathbf{U}_{2 \max }[\mathbf{V}]$ & $\mathbf{I}_{2 \max }[\mathbf{A}]$ & $\mathbf{k}$ \\
\hline 5 & 145.8 & $\begin{array}{c}1.99 \\
(8)\end{array}$ & $+0.048-0.023$ & & $\begin{array}{c}1.85 \\
(6.46)\end{array}$ & $\begin{array}{c}0.029 \\
(0.27)\end{array}$ & 0.93 \\
\hline & & $\begin{array}{c}1.88 \\
(8)\end{array}$ & $\begin{array}{c}0.2 \\
(0.57)\end{array}$ & 191 & $\begin{array}{c}1.5 \\
(4.28)\end{array}$ & $\begin{array}{c}0.05 \\
(0.14)\end{array}$ & 0.79 \\
\hline 10 & 173.5 & $\begin{array}{c}2.438 \\
(8)\end{array}$ & 0.049 & & $\begin{array}{c}1.64 \\
(4.69)\end{array}$ & $\begin{array}{c}0.0287 \\
(0.07)\end{array}$ & 0.67 \\
\hline 15 & 165.7 & 5.67 & $\begin{array}{c}0.029 / \\
0.0208\end{array}$ & & $\begin{array}{c}2.08 \\
(2.54)\end{array}$ & 0.0325 & 0.365 \\
\hline 20 & 166 & 6.95 & $\begin{array}{c}+0.019 / \\
-0.016\end{array}$ & & $\begin{array}{c}1.16 \\
(1.16)\end{array}$ & 0.020 & 0.167 \\
\hline
\end{tabular}


The applied compensation (resonant) capacitor are $C_{1}=C_{2}=0.2 \mu F$ and the load was $\mathrm{R}_{\text {load }}=54 \Omega$. Table. 1 reveals the resonant frequencies in both sides of the transceiver and their measured values of voltage and current. The correlation $k=U_{1} / U_{2}$ for different distances is also presented. Values in parenthesis represent samples in the same conditions for different levels of power.

\subsection{Second Experiment - HF Vacuum Tube Generator}

The power for this experiment was higher. The same ferrite core was used (Fig.4).

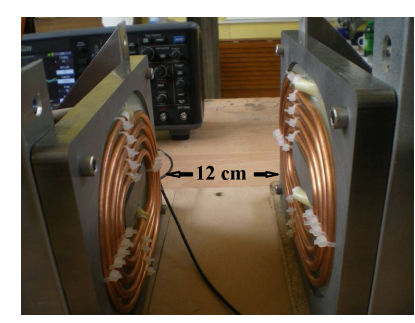

Fig. 4. Transmitter with FLUXTROL 50 ferrite.

The experimented distance between the coils was $120 \mathrm{~mm}$ and the compensation was made at the high voltage side of the transformer by capacitance $\mathrm{C}_{1}=5000 \mathrm{pF}$. The second coil is compensated by a capacitor $\mathrm{C}_{2}=3 \times 6800 \mathrm{pF}=20400 \mathrm{pF}$. The load is $R_{\text {load }}=160 \Omega(1,2,3)$ or $R_{\text {load }}=60 \Omega(4)$. The resonant frequency of the receiver is $\mathrm{f}_{2 \mathrm{r}}=509.7 \mathrm{kHz}$ and the operating frequency is $\mathrm{f}=533 \mathrm{kHz}$.

Table 2. Circuit parameters for $\mathrm{f}=533 \mathrm{kHz}$.

\begin{tabular}{|c|c|c|c|c|c|c|c|c|c|}
\hline $\begin{array}{c}\mathbf{U}_{\text {1ef }} \\
{[\mathbf{V}]}\end{array}$ & $\begin{array}{c}\mathbf{I}_{\mathbf{1 e f}} \\
{[\mathbf{A}]}\end{array}$ & $\begin{array}{c}\boldsymbol{\varphi}_{\mathbf{1}} \\
{\left[{ }^{\circ}\right]}\end{array}$ & $\begin{array}{c}\mathbf{P}_{\mathbf{1}} \\
{[\mathbf{W}]}\end{array}$ & $\mathbf{U}_{\mathbf{2 e f}}[\mathbf{V}]$ & $\begin{array}{c}\mathbf{I}_{2 \text { ef }} \\
{[\mathbf{A}]}\end{array}$ & $\begin{array}{c}\boldsymbol{\varphi}_{\mathbf{2}} \\
{\left[{ }^{\circ}\right]}\end{array}$ & $\begin{array}{c}\mathbf{P}_{\mathbf{2}} \\
{[\mathbf{W}]}\end{array}$ & $\boldsymbol{\eta}$ & $\begin{array}{c}\mathbf{R}_{\text {load }} \\
{[\mathbf{\Omega}]}\end{array}$ \\
\hline 187.4 & 12.02 & 88.2 & 70.75 & 76.36 & 0.707 & 9 & 53.32 & 0.75 & 160 \\
\hline 281.0 & 18.03 & 88.2 & 159.12 & 115.25 & 0.99 & 9 & 112.68 & 0.72 & 160 \\
\hline 374.7 & 24 & 88.2 & 282.47 & 154 & 1.30 & 9 & 198.9 & 0.71 & 160 \\
\hline 561.7 & 36.0 & 88.2 & 635.00 & 229 & 2.12 & 9 & 479.8 & 0.75 & 60 \\
\hline
\end{tabular}

The primary circuit presents the expected inductive behavior, as shown in Table. 2 by the phase shift $\varphi_{1}=88.2^{\circ}$. The efficiency is high. A slightly inductive shift from the resonance is observed in the secondary $\left(\varphi_{2}=9^{\circ}\right)$. For the operation frequency $f=$ $533 \mathrm{kHz}$ and $\mathrm{D}=12 \mathrm{~cm}$ the output power is $\mathrm{P}_{2}=479.8 \mathrm{~W}$ and the efficiency is $75 \%$. 


\subsection{Third Experiment - MOSFET Inverter with Auto Generation}

This experiment was prepared with the necessary rectifier and regulator circuit that permitted to charge a battery by WET. The equipment used in this case is a high frequency power converter implemented by MOSFET which is prepared for melting of gold. The resonant compensation is made both in primary and secondary sides by capacitors $C_{1}=C_{2}=0.2 \mu \mathrm{F}$. The input DC voltage is fixed at $U_{d}=30 \mathrm{~V}$. For the distances higher than $10 \mathrm{~cm}$ another voltage source was joined in series.

Table 3. Circuit parameters with $\mathrm{f}_{\mathrm{r}}=177 \mathrm{kHz}$.

\begin{tabular}{|c|c|c|c|c|c|c|c|c|}
\hline $\begin{array}{c}\mathbf{D} \\
{[\mathbf{c m}]}\end{array}$ & $\begin{array}{c}\mathbf{f}_{\mathbf{1}} \\
{[\mathbf{k H z}]}\end{array}$ & $\begin{array}{c}\mathbf{U}_{\mathbf{0}} \\
{[\mathbf{V}]}\end{array}$ & $\begin{array}{c}\mathbf{U}_{\mathbf{1 m a x}} \\
{[\mathbf{V}]}\end{array}$ & $\begin{array}{c}\mathbf{I}_{\mathbf{1 r m s}} \\
{[\mathbf{A}]}\end{array}$ & $\begin{array}{c}\mathbf{U}_{2 \max } \\
{[\mathbf{V}]}\end{array}$ & $\begin{array}{c}\mathbf{I}_{2 \text { rms }} \\
{[\mathbf{A}]}\end{array}$ & $\boldsymbol{\varphi}\left[{ }^{\circ}\right]$ & $\begin{array}{c}\mathbf{U}_{\mathbf{0 u t}} \\
{[\mathbf{V}]}\end{array}$ \\
\hline 5 & 226 & 30 & 75.5 & 9.5 & 21.27 & 0.328 & 16.36 & 14.2 \\
\hline 10 & 225.78 & & 74.33 & 10 & 6.14 & 0.172 & 55.6 & 3.92 \\
\hline 15 & 225.6 & & 75.13 & 10.4 & 2.64 & 0.106 & 0.365 & 1.14 \\
\hline 20 & 225.3 & & 75.13 & 10.6 & 0.2 & 0.084 & 0.167 & 0.28 \\
\hline
\end{tabular}

\subsection{Fourth Experiment - MOSFET, Phase Shift Regulated and Full Bridge Inverter}

The power converter used in this experiment was prepared for several $\mathrm{kW}$. The operating frequency range was $100-200 \mathrm{kHz}$. The compensation is made by $\mathrm{C}_{1}=\mathrm{C}_{2}=$ $0.2 \mu \mathrm{F}$, the experimented distance is $\mathrm{D}=100 \mathrm{~mm}$ or $\mathrm{D}=150 \mathrm{~mm}$. The load was changed between 2.5 and $95 \Omega$. In this experiment the coils had to be water cooled, because of the higher currents. The resonant frequency is measured at $f_{r}=184 \mathrm{kHz}$.

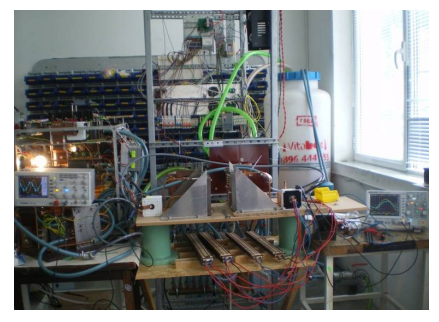

Fig. 5. High power MOSFET inverter.

The experimental results and the circuit parameters are presented in Table.4. The obtained efficiency is $\eta=70 \%$ for the $\mathrm{D}=10 \mathrm{~cm}, \mathrm{U}_{1}=600 \mathrm{~V}, \mathrm{I}_{1}=24 \mathrm{~A}$ and $\mathrm{R}_{\text {load }}=$ $11.5 \Omega$ or $\mathrm{R}_{\text {load }}=2.5 \Omega$. For the same input voltage and current and load $\mathrm{R}_{\text {load }}=16.7$ $\Omega$ the efficiency goes higher, $\eta=75.1 \%$ (Table.4). 
Table 4. Inverter and sender side circuit parameters at frequency around $180 \mathrm{kHz}$.

\begin{tabular}{|c|c|c|c|c|c|c|c|c|c|c|}
\hline $\begin{array}{c}\mathbf{D} \\
{[\mathbf{c m}]}\end{array}$ & $\begin{array}{c}\mathbf{U}_{\mathbf{1}} \\
{\left[\mathbf{V}_{\mathbf{m a x}}\right]}\end{array}$ & $\begin{array}{c}\mathbf{I}_{\mathbf{1}} \\
{\left[\mathbf{A}_{\mathbf{m a x}}\right]}\end{array}$ & $\begin{array}{c}\boldsymbol{\varphi}_{\mathbf{1}} \\
{\left[{ }^{\circ}\right]}\end{array}$ & $\begin{array}{c}\mathbf{P}_{\mathbf{1}} \\
{[\mathbf{W}]}\end{array}$ & $\begin{array}{c}\mathbf{R}_{\mathbf{l o a d}} \\
{[\mathbf{\Omega}]}\end{array}$ & $\begin{array}{c}\mathbf{U}_{\mathbf{2}} \\
{\left[\mathbf{V}_{\mathbf{m a x}}\right]}\end{array}$ & $\begin{array}{c}\mathbf{I}_{\mathbf{2}} \\
{\left[\mathbf{A}_{\mathbf{m a x}}\right]}\end{array}$ & $\begin{array}{c}\boldsymbol{\varphi}_{2} \\
{\left[{ }^{\circ}\right]}\end{array}$ & $\begin{array}{c}\mathbf{P}_{\mathbf{2}} \\
{[\mathbf{W}]}\end{array}$ & $\begin{array}{c}\mathbf{\eta} \\
{[\%]}\end{array}$ \\
\hline & 200 & 7.2 & 52.4 & 439 & 95 & 71.25 & 2.68 & 26.2 & 86 & 19.5 \\
\cline { 2 - 12 } & 350 & 12 & 75.6 & 522 & & 88.75 & 3.1 & 26.6 & 123 & 23.6 \\
\cline { 2 - 11 } & 300 & 10.8 & 75.6 & 403 & 50 & 116 & 3.74 & 26.6 & 194 & 48.1 \\
\cline { 2 - 11 } 10 & 300 & 12 & 75.6 & 448 & 16.7 & 132.14 & 4.8 & 26.6 & 284 & 63.3 \\
\cline { 2 - 11 } & 600 & 24 & 80.0 & 1250 & & 244.28 & 8.6 & 26.6 & 939 & 75.1 \\
\cline { 2 - 11 } & 600 & 24 & 80.2 & 1228 & 11.5 & 228 & 8.4 & 24.9 & 869 & 70.7 \\
\cline { 2 - 10 } & 600 & 24 & 78.8 & 1405 & 2.5 & 182 & 12.78 & 32.1 & 985 & 70.1 \\
\hline \multirow{2}{*}{15} & 600 & 24 & 85.3 & 590 & 2.5 & 102.21 & 7.55 & 32.1 & 327 & 55.4 \\
\hline
\end{tabular}

The waveforms of the primary voltage and current for the best efficiency case are presented in Fig.6. For the secondary circuit, the current waveform is presented in Fig.7.

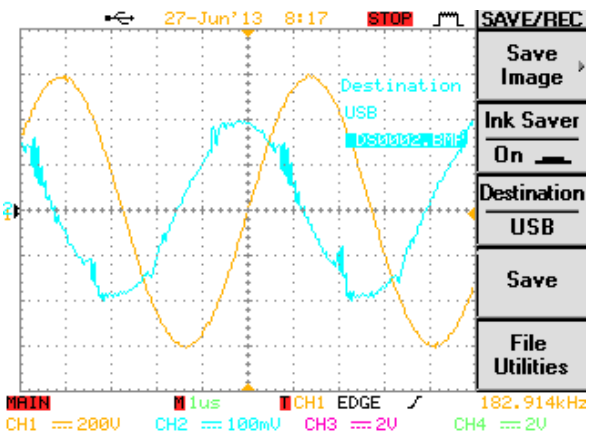

Fig. 6. Waveforms of the current $I_{1}$ and the voltage $\mathrm{U}_{1}$.

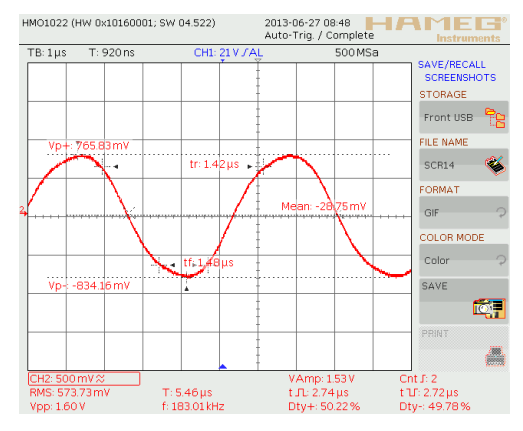

Fig. 7. Waveforms of the current $\mathrm{I}_{2}$.

\section{Conclusions}

The comparative analysis of the experimental results reveals the complexity of the problems and results in the following conclusions: the efficiency is related to the frequency and at the same frequency it is related to the load. The highest obtained 
output voltage depends on the input voltage and the distance transmitter/receiver. For these generators a cooling was needed at the highest transferred power.

In conclusion, the experiments have proven that the existing induction heating equipment can be used as a base for developing the new WET technology, especially for charging the batteries of the EV. It is a fast solution that can achieve a better cooperation between the electric vehicles and the grid.

Acknowledgments. The authors fully recognize the support from the European Commission FP7 project DERri GA No 228449 (http://www.der-ri.net). The authors are entirely responsible for the content of this publication. It does not represent the opinion of the European Community. We thank equally the enterprise Apronecs that allowed us to experiment at higher power.

\section{References}

1. Valtchev, S., Klaassens, J.B.: Efficient Resonant Power Conversion. In: IEEE Transactions on Industrial Electronics, vol. 37, no. 6, pp. 490--495 (1990)

2. Wang, C.S., Stielau, O.H., Covic, G.A.: Design Considerations for a Contactless Electric Vehicle Battery Charger. In: IEEE Transactions on Industrial. Electronics, vol. 52, no. 5, pp. 1308--1314 (2005)

3. Rossetto, L.: A Simple Control Technique for Series Resonant Converters. In: IEEE Transactions on Power Electronics, vol. 11, no. 4, pp. 554--560 (1996)

4. Moradewicz, A., Kazmierkowski, M.: FPGA Based Control of Series Resonant Converter for Contactless Power Supply. In IEEE International Symposium on Industrial Electronics, pp. 245--250 (2008)

5. Valtchev, S., Brandisky, K., Borges, B., Klaassens, J.B.: Resonant Contactless Energy Transfer with Improved Efficiency. In: IEEE Transactions on Power Electronics, vol. 24, no. 3, pp. 685--699 (2009)

6. Delphi Media Releases, http://delphi.com/about/news/media/pressReleases/pr_2010_09_29_001/

7. Yuwei , Z., Xueliang, H, Linlin, T., Yang, B, Jianhua, Z.: Current Research Situation and Developing Tendency about Wireless Power Transmission. In: International Conference on Electrical and Control Engineering, pp. 3507--3511, Wuhan (2010)

8. Lee, S., Huh, J., Park, C., Choi, N., Cho, G., Rim, C.: On-Line Electric Vehicle Using Inductive Power Transfer System. In: 2nd IEEE Energy Conversion Congress and Exposition, pp. 1598--1601, Atlanta (2010)

9. Park, M., Shin, E., Lee, H., Suh, I.: Dynamic Model and Control Algorithm of HVAC System for OLEV® Application. In: International Conference on Control Automation and Systems, pp. 1312--1317, Gyeonggi-do (2010) 